\title{
Innovation: Crucial Factor for the Internationalization of SMEs
}

\author{
Maria Navarrete-Hinojosa ${ }^{1}$, Jaime Olea-Miranda ${ }^{1}$, Ricardo Rodriguez-Carvajal ${ }^{1}$, Lucas-Ruiz Duarte ${ }^{1}$, Jorge \\ Taddei-Bringas $^{1}$ \\ ${ }^{1}$ Department of Industrial Engineering, University of Sonora, Mexico. \\ Correspondence: Jorge Taddei-Bringas, Department of Industrial Engineering, University of Sonora. Rosales Boulevard \\ corner Luis Encinas Boulevard, Hermosillo, Mexico.
}

\author{
Received: January 4, 2015 \\ Accepted: January 19, 2015 \\ Available online: January 20, 2016 \\ doi:10.11114/ijsss.v4i2.1275 \\ URL: http://dx.doi.org/10.11114/ijsss.v4i2.1275
}

\begin{abstract}
Market globalization has brought profound changes in the way in which relations between people, companies and countries are established. Particularly for companies, these changes have manifested in an increase in international operations, which on one hand press local micro, small and medium firms (SMEs) to improve their products and processes, so that they do not be displaced by foreign companies, but on the other, this new environment offers them opportunities to access foreign markets.

There are several approaches to understand the elements that influence the internationalization of firms; some of them are based on the input directly to the foreign market. In the case of SMEs, additionally, it has been proposed as a mechanism of internationalization, their direct participation in global value chains (GVC). One of the ways for consolidate the participation of SMEs in GVCs is through innovation.

The purpose of this article is to present a model based on innovation, which summarizes the ideas of several authors as a factor explaining the internationalization of SMEs, particularly in the sectors of metalworking and information technology, located in the state of Sonora, Mexico. Considered factors are entrepreneurial orientation, organisational competitions, institutions and capital. To validate the hypothesis and use of the proposed model, a survey was applied to 116 SMEs from Sonora; using a logistic regression technique, a probability function was calculated. Results can help to understand some of the elements that are present in this complex process of integration of SMEs in global value chains.
\end{abstract}

Keywords: internationalization, innovation, SMEs, global value chains

\section{Background}

From the early 1970s, great changes have been brought about by globalization of the economy, including the signing of international trade agreements, economic liberalization and the emergence of low cost technologies that "join people and places" (Oyson, 2011, p.101). This process of industrial restructuring and deregulation of markets may be summarized as "the integration of world trade and disintegration of production" (Feenstra, 1998, p.1). These conditions have led to the international expansion of firms seeking to take advantage of new opportunities arising in foreign markets.

In the other hand, SMEs in developing countries play an important role in the economies of countries by the number of establishments and jobs created (Korsakiene, 2014); but by the globalization effect, they have been faced with international competition, forcing them to understand the constraints that affect the achievement of their successful participation in these markets, which are new to them (Korsakiene and Tvaronaviciene, 2012)..

There are a number of strategies that a company can implement to internationalize: export; foreign direct investment (FDI); licensing; outsourcing; franchising; joint ventures; and. the establishment of subsidiaries (Lopez and Ruiz, 1996). However, more and more, organizations are becoming internationalized through integration into global value chains and global production networks (Alonso, 2007).

Global value chains (GVC) represent a new form of industrial organization that has gained acceptance in many industries in different countries (Guiliani, Pietrobelli and Rabelloti, 2005; Morrison, Pietrobelli and Rabelloti, 2008). In the case of small suppliers in underdeveloped countries, it presents one of the most common options for accessing international markets, diversifying exports, creating new jobs, updating knowledge, and acquiring new technological and innovation capacities, thereby strengthening the their countries' competitiveness (Kosakoffi and López, 2008; 
Pietrobelli and Rabelloti, 2009).

The success of internationalization depends on several factors, most notably those affecting the economy as a whole, such as the availability of production resources and the existence of infrastructure services. It further depends on the existence of policies and institutions that support industrial growth, in addition to factors related to technology, production and innovation capabilities, all of which allow the harnessing of opportunities in the international market (Alonso, 2007).

In recent years, the Organization for Economic Cooperation and Development (OECD, 2004) has shown that innovation has become a factor that not only improves productivity and, therefore, competitiveness but also drives economic development and integrates SMEs into global production chains thereby ensuring their exposure to international markets.

This articleto aims to show the relationship between innovation and internationalization of a SME. The article consists of five sections and a conclusion: the first section presents the background; this is followed by a synthesis of theories and models on internationalization and innovation; the third section focuses on SMEs in the sectors of information technology and metalworking in Sonora; the following section sets forth the methodology and the fifth section discusses the results of the study. Finally, the conclusions are presented

\section{Method}

\subsection{Theories and models of internationalization of firms}

Internationalization has been defined in several ways: for Korsakiene and Tvaronoviciene (2012, p.296), it is "the expansion of the company's operations in foreign markets". Oviatt and McDougall (2005, p.540), referring to international entrepreneurship, conceptualised the concept as the "discovery, evaluation and exploitation of opportunities beyond national boundaries to create future products and services". Meanwhile, Ruzzier, Antoncic, Hisrich and Konecnik (2007, p.16), inspired by a vision based on resources, defined the concept as "the process to mobilize, build and develop a set of resources to carry out international activities".

The process of SMEs' internationalization is explained by different authors and theoretical approaches. It has been attributed to the internationalization theory (Buckley and Casson, 1985), to the Uppsala model proposed by Vahlne and Johanson (1977), to international entrepreneurship (Oviatt and McDougall 2005) and to the theory of networks formulated by Vahlne and Johanson (2009). For more depth on the issue, Fernández-Ortiz, San Emeterio and Menorca (2012) have provided a summary of the different types of approaches to, and of the authors who have developed models of firms' internationalization.

As the processes that companies follow to achieve internationalization are complex, and as existing models provide only a partial explanation for the mechanisms of export development (Leonidou and Katsikeas, 1997), in addition to theoretical approaches, various holistic models have emerged which integrate various variables of the theoretical perspectives. Likewise, Etemad and Wright $(1999$, p.9) concluded that "no simple model adequately explains the success of some companies to internationalize".

With reference to the particular case of SMEs, Jamali, Jawad Shaikh, Shaikh and Afridi (2011), developed a model of internationalization of the firm, which included relevant factors touching on the following variables: company demographics (age, size, location and source); firm resources (financial, physical, human, technological, and organizational reputation); and, senior management features (dominating languages, previous experience, education and administrative background).

\subsection{Theories and models of firm innovation}

According to the Oslo Manual (OECD, 2005, p.56) innovation must be understood by "the introduction of a new or significantly improved product (good or service), process, a new marketing method or a new organizational method in the internal practices of the company, workplace organization or external relations".

It is widely recognized that innovations have significant effects on productivity, competitiveness and employment (Kuster and Vila, 2011; Valenti, 2008). The opportunity to internationalize in new markets requires products and services tailored to local needs (Buse, Tiwari and Herstatt, 2010), which necessarily implies the ability to innovate. In addition, if firms seek a sustainable advantage, it is necessary to continually develop innovations as competitors can quickly imitate the products on the market.

Despite the advantages that can be achieved by internationalization, the barriers that SMEs face in serving foreign markets (Leonidou, 2004; London, 2010) are both internal and external. Internal hurdles include lack of information and equity, difficulties in innovating, hurdles to building international market positions, problems in maintaining international business relations, and, obstacles to developing language skills. External obstacles include standardization, 
quality requirements, conformity assessment, and differences in packaging, labelling, and ecological requirements.

Several models have been developed to conceptualize innovation. Sheng Wang, Xu, Li and Liu (2009) presented a model that identified three factors (resources, capabilities and environment) that supported "the innovation system of the company". Resources may be tangible - talented entrepreneurs with initiative, R \& D, and infrastructure for innovation- or intangible- such as knowledge, information, capital, and intellectual property-. The capabilities are developed to integrate resources to provide better solutions to the problems of innovation. Finally, the uncertainty of the environment refers not only to the degree of competitive rivalry, but also to the stability of market demand, and to government policies and the situation of the industry in general.

In order to understand the elements that impact innovation, Zawislak, Borges, Wegner, Castro-Santos and Lucas (2008) presented the concept "innovation function". For these authors, innovation is a function of entrepreneurship (will, desire, spirit, courage and vision to carry out new ideas), institutions (social-economic and cultural context in which entrepreneurs explore opportunities), capabilities (resources, skills, abilities and skills to turn ideas into products and services), and, capital (financial resources needed to sustain the entire process).

\section{Proposed model and validation methodology}

\subsection{The model}

The model proposed in this article, gleaning ideas from the models of "the innovation system of the company" (Shen et al., 2009) and the "innovation function" (Zawislak et al., 2008), highlights the impact of innovation in the internationalization of firms. The model is summarized in the following concepts and dimensions shown in Figure 1 and are explained later.

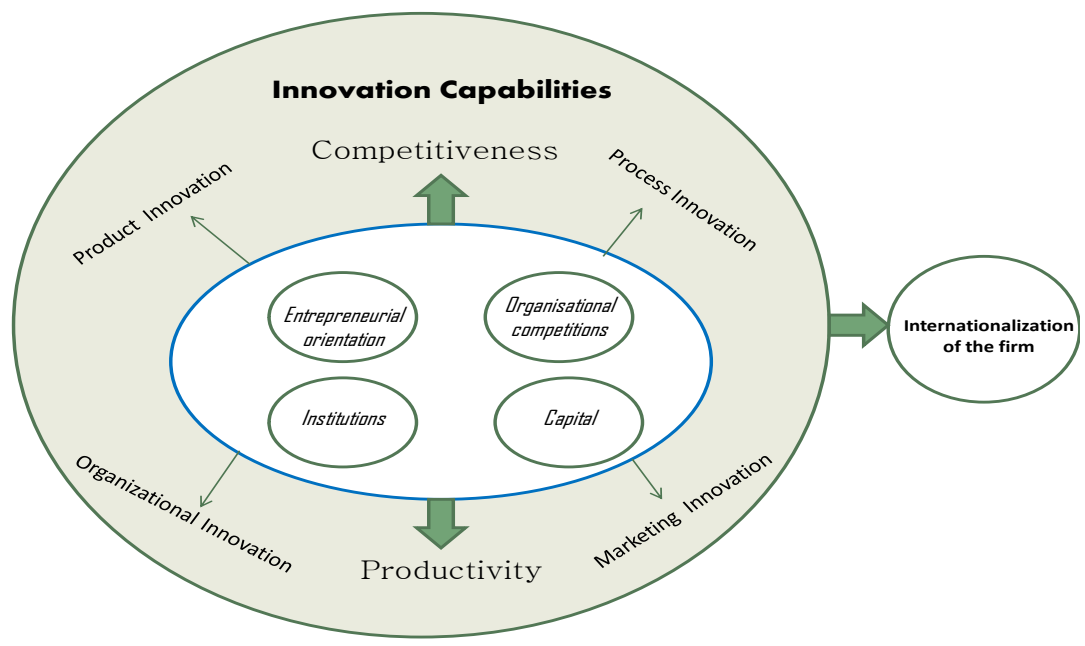

Figure 1. Internationalization of firms in terms of innovation capabilities. Prepared with reference to Shen et al. (2009) and Zawislak et al. (2008)

The entrepreneurial orientation. In the innovation process, an entrepreneur with culture, knowledge, insight and a willingness to take risks is required; therefore, the previous experience and educational level of the decision maker are significant considerations.

Institutions have the function of reducing uncertainty by defining "rules", such as standards or codes of conduct. It is recognized that, if institutions do not offer opportunities to firms to improve their innovation processes, their internal capabilities will not be sufficient to advance and compete internationally. Among the institutions with a role to play in this regard are the government, universities and research centres. Porter and Stern (2001) applied the term "external environment for innovation" to these inputs, whereas Valenti (2008) referred to such influences as the characteristics of the context and the coordinative capacity of the agents involved.

Organizational competitions are investments in research and development to generate new knowledge. We can distinguish between domestic investment, which is designed to improve the staff and assets of the company, and external investments, which are made by the conclusion of agreements with other firms, universities or research centers. The capacity of companies to generate new processes and products by harnessing both the knowledge of their personnel and the capabilities of their technologies has been referred to by Porter and Stern (2001) as "internal factors". In a similar vein, Valenti (2008) describes such innovation as "the factor that gives the main comparative advantage". Hence, in the proposed model, the level of knowledge, education and training of staff are considered as related to the individual's knowledge; related with technology, the age of the equipment and the qualification that the owner makes on the technology of his company in relation to the technology used worldwide. Finally, it is included as a capacity of 
the company if it has a certification, because this may allow international operations.

The Capital refers to the financial resources necessary to cover expenses that arise in the process of innovation. To evaluate this aspect, the model uses two key input parameters: average investment in projects and funding sources.

These elements potentiate product innovations, process, organizational efficiency and marketing effectiveness, which are regarded as the cornerstones of competitiveness and productivity. The dynamic generated by these elements paves the way to the internationalization of firms.

In order to validate the proposed model, a survey was carried out on 116 SMEs in the information technology and metalworking sectors in Sonora. The state of Sonora is in the northwest of the country and is the second largest state in Mexico, representing 9.2\% of the total land area; it shares borders with the United States including the states of Arizona and New Mexico. Figure 2.

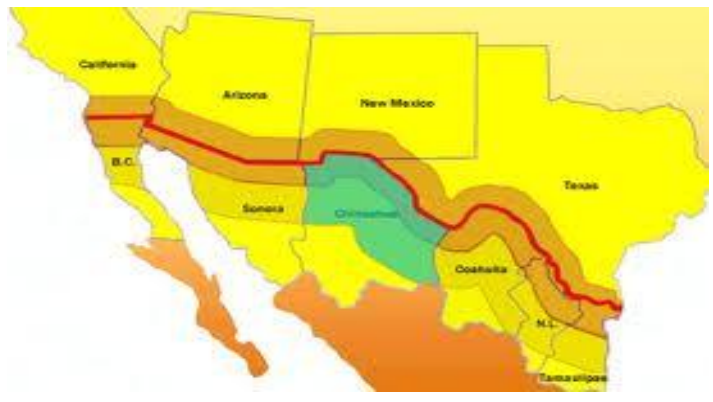

Figure 2. Boundary of the state of Sonora, Mexico with the United States

SMEs have a huge potential to contribute to economic growth and development. In the EU, $99 \%$ of all companies contribute more than two thirds of its GDP and provide 75 million jobs in the private sector (Cordis, 2009).

In Mexico, the economic pattern is similar. According to data provided by the Ministry of Economy in September 2014, SMEs generated $51 \%$ of GDP and contributed to $72 \%$ of formal employment. In particular, in the state of Sonora, SMEs represented $98 \%$ of all industrial enterprises (SIEM http: /www.siem.gob.mx).

The economy of Sonora has undergone a restructuring process in the past 25 years, mainly due to the automotive industry and assembly plants, which have generated a polarized industrial structure, exemplified by a significant increase in advanced manufacturing activity; this has created a dynamic in which most local small businesses have struggled to participate in the new opportunities. However, a small number of local companies, taking advantage of the open spaces by the leading companies for an interactive learning, from demand of supplies and services, have overcome the barriers, becoming producers of capital goods and specialized services, enabling them strengthen their capabilities as reliable suppliers (Contreras and Olea, 2005).

\subsection{Methodology}

The empirical study is based on a survey which was designed as part of the research project "Global Production Networks and local learning: spills of transnational technological and absorptive capacity in technology-based SMEs in Northwestern Mexico", COLEF-COLSON, Conacyt No. 133596.

A fieldwork instrument for data collection was developed. It consisted on a survey integrated by 95 questions divided in ten sections, as follows: I. General data, II. Absorption capacity, III. Learning and technological innovation, IV. Relations with other companies, V. Relations with educational institutions, VI. Relations with government, VII. Relations with Business Chambers, VIII. Product identification, IX. Strategic direction and management, and X. Investment.

Directories of companies that are established in the state of Sonora were used to develop the sampling frame, obtaining 32,343 records. Some of the directories consulted include: economic activity records of the Mexican Social Security Institute (IMSS, for its acronym in Spanish); the Mexican Business Information System (SIEM, for its acronym in Spanish); the directory of the National Chamber of the Manufacturing Industry; the Yellow Pages Phone Book, among others.

A filter for main activity, size and municipality criteria was applied on the database records; the own existence, main economic activity and geographic location were verified for each company.

A thorough depuration of the list of MM and IT businesses resulted on 672 economic units that could be considered (322 of IT and 350 of MM). Blacksmith workshops, radio broadcasters and cyber cafe were excluded.

Sample size was determined using the formula for sample proportion with a 10 percent accuracy level and a confidence 
level of 95 percent, as follows:

$$
n=\left(\frac{Z_{(1-\alpha / 2)}^{2} p q N}{N \varepsilon^{2}+Z_{(1-\alpha / 2)}^{2} p q}\right) f \quad \text { Equation } 1
$$

Where:

$\mathrm{n}$ = sample size

$\mathrm{N}=$ Population size

Z2 $(1-\alpha / 2)=$ Confidence level

$\mathrm{p}=$ positive Variability

$\mathrm{q}=$ negative Variability

$\varepsilon=$ Accuracy or error

$\mathrm{f}=$ error and nonresponse correction factor

As was mentioned in the previous section, in our case, a survey of 116 micro, small and medium enterprises (SMEs) in the information technology (55) and metal mechanics (61) sectors was carried out in six Sonora municipalities where there was a concentration of economic activity.

The objective was to measure the impact of innovation in the insertion of an SME in the CGV; it was decided to include in the model the type of activity and the size of the enterprise, as these variables can influence to accept a local SME as a provider of a foreign enterprise, as shown by previous studies (Contreras and Olea, 2005). In addition, companies that have relation with transnational supply were classified.

The central hypothesis of this study is that the activities, size and innovation capabilities of SMEs are factors that strengthen their chances of becoming internationalized.

Company activity (activity). The sample companies were grouped into two types of activities: 1) Information Technology (IT) which included: computer consulting services and software development, (but excluded radio broadcasters and internet cafe); and 2) Metalworking (MM) groups which encompassed: fabrication of metal products; metal parts machining; manufacturing of screws, metal structures, bodies and trailers, industrial machinery and equipment; repair, installation and maintenance of machinery and industrial equipment; and, industrial precision (blacksmith workshops were excluded).

Company size (Size). The INEGI classification criteria of "Small and Medium Enterprises" (Table 1) were followed.

Table 1. Classification of company size

\begin{tabular}{|c|c|c|}
\hline \multirow{2}{*}{ Classification } & \multicolumn{2}{|c|}{ Number of employees } \\
\hline & Industry & Services \\
\hline Micro & from 1 to 30 & from 1 to 20 \\
\hline Small & from 31 to 100 & from 21 to 50 \\
\hline Medium & from 101 to 250 & from 51 to 100 \\
\hline
\end{tabular}

Source: INEGI, (2011). Economic Census 2009

An innovation capabilities indicator (CAPINNO) was calculated from the applicable variables that comprised: entrepreneurial orientation, institutions, organizational skills, capital, and type of innovation.

The entrepreneurial orientation indicator was constructed with reference to items related to the level of education and work experience of the owner, the innovation strategy, the objectives of the enterprise, the methodology to prioritise and target resources, and the implementation of activities for dismantling the barriers to competing abroad.

Institutions' dimension was built with reference to items related to the types of support received from goverrment, higher education institutions, and associations or chambers for product development, in addition to information sources and agents that influence learning of company members.

The Organizational Skills dimension was generated using items related to the education and training level of workers, the training plan of the company, the technology used, age of equipment, possession of certifications, and strategies implemented in the previous five years.

The Capital dimension was constructed using items related to investment projects, the sources of funds for investment, and the types of projects that had been supported.

Innovation indicators were developed with reference to items related to the implementation of new or improved products as well as to significant changes in organizational and marketing activities.

CAPINNO was defined as a scale variable which includes the above four dimensions, according to the recommended 
Schuschny and Soto (2009) procedure. It consists on building indexes from weighted averages, or through the sum of the responses of the items for each factor or variable (the factors considered in this case are Entrepreneurial Orientation, Organizational Competitions, Institutions and Capital). Since the proposed factor indicators were measured at different scales, it was necessary to standardize them before being added (Hernández, Fernández and Baptista, 2009; Schuschny and Soto, 2009).

For analysis, a logistic regression model -Probit- (LR) was selected, which was of the multivariate model type, which is used where it is sought to establish the influence that a number of independent and control variables have on a dichotomous dependent variable $(0 / 1$; No, Yes). The aim was to express the probability of an event as a function of the variables that were relevant or influential or presumed to have occurred.

Choosing the LR model also allowed the following advantages: 1) the entry of a mixture of categorical and quantitative variables as response predictors, 2 ) from the regression coefficients $(\beta)$ of the independent variables, the Odds Ratio (OR) could be directly obtained, corresponding to the probability of having an evaluated effect for a given value (x) from the value decreased by a unit (x-1) (Aguayo, 2007).

To implement the LR model, it was necessary to determine both the relevant variables and the manner in which they would join to the model:

Dependent variable: internationalization. It was this variable we sought to model in order to elicit dichotomous responses (No, Yes).

Predictor variables (independent): company size (micro, small and medium) and innovation capacities (low, medium, high). These were the variables we sought to model and also to assess their relationship or association with the dependent variable.

Confounding variable: Company activity. Predictor of response or effect, outside the primary relationship analyzed (X $\rightarrow \mathrm{Y}$ ); they are not an intermediate step between exposure and response, but simultaneously are related to the independent variables. In this case, literature puts IT companies and MM as the industry types most likely to join global value chains (Contreras y Olea, 2005). In addition, the geographical context (by virtue of the proximity of the USA) potentiates the links with foreign markets and sales.

The exposed variables were introduced in the model and the statistic package SPSS V.20 was used for their calculation It is necessary to consider the following findings for better understanding and interpretation of the results:

- The empirical study comprised 116 cases, 55 IT companies and $61 \mathrm{MM}$.

- The encoding used for the dependent variable took the value 1 which identified the evaluated result (in our case "internationalization"). This allowed a better understanding of the $\beta \mathrm{i}$ coefficients of the independent and control variables: a positive regression coefficient indicated that the probability of achieving internationalization increased when moving from one category to another: micro, small and medium in size, or, basic, intermediate and advanced capabilities for innovation.

- The control variable (business activity) coded as $0=\mathrm{MM}$ and $1=\mathrm{IT}$, was the reference in obtaining the probability of achieving the internationalization of IT companies against companies MM.

The main results and interpretations are listed below:

\section{Analysis of results}

As a first step, it fell to be considered whether the value of the constant in the equation was necessary. Table 2 shows the estimated value of the parameter $(\beta=-.642)$, its standard error (SE), and its statistical significance with the Wald test, which followed a chi-square distribution with 1 degree of freedom $(\mathrm{df})$ - and estimating OR (exp $(\beta))$. The value of the Wald statistic $(10,797)$ and its significance $(0.001)$ indicated that this coefficient was equal to 0 ; therefore, the constant had to be incorporated into the model.

Table 2. Variables on the equation

\begin{tabular}{cccccccc}
\hline & & B & E.T. & Wald & gl & Sig. & $\operatorname{Exp(B)}$ \\
\hline Step 0 & Constant &,- 642 &, 195 & 10,797 & 1 &, 001 &, 526 \\
\hline
\end{tabular}

Following integration of the independent variables, a diagnostic test was carried out, which permitted evaluation of the fit of the regression model based on a comparison of the predicted values with those observed. The results are presented in Table 3. The results showed a specificity of $85.5 \%$ and a sensitivity of $67.5 \%$ (Alderete, 2006). Thus, we can say that the model was considered a good fit because the overall percentage of explanation was set at $79.3 \%$.

Table 3. Diagnostic Test

\begin{tabular}{ccccc}
\hline & & \multicolumn{2}{c}{ Predicted } & \\
\cline { 3 - 3 } Observed & & No & Yes & $\begin{array}{c}\text { Correct } \\
\text { percentage }\end{array}$ \\
\cline { 3 - 4 } Internacionalization & No & 65 & 11 & 85,5 \\
Global percentage & Yes & 13 & 27 & 67,5 \\
& & & & 79,3 \\
\hline
\end{tabular}


Finally, Table 4 presents variables to be considered in the equation: regression coefficients (Bi) with their corresponding standard errors (ET); Wald statistic to evaluate the null hypothesis $(\beta i=0)$; and, associated statistical significance and value of the OR (exp ( $\beta)$ ) with confidence intervals (Table 4).

One of the features that enhances the value of the LR model, is the relationship the coefficients have with the parameter for quantifying risk, known as the odds ratio (OR) and the mathematical properties of these (Aguayo, 2007). The notion being measured with the odds associated with an event is the ratio between the probabilities of occurrence against the probability of non-occurrence. In the present case, the innovation capacities were designed as a measure that quantified the change in risk (internationalization), in travelling from one value to another (low, medium or high), where other variables remained constant. Thus we can say that SMEs were 4.361 times more likely to be internationalized when their innovation capabilities went from basic to intermediate, or from intermediate to advanced.

It should be clarified that, for ease of analysis and considering that the CAPINNO variable is normalized (values between 0 and 1), the cutoff points for the ranges were defined as between 0 to 0.33 for low innovation capabilities , from 0.34 to 0.66 and $0.67-1.00$ for intermediate to high.

Table 4. Variables in the equation

\begin{tabular}{|c|c|c|c|c|c|c|c|c|c|}
\hline & & & & & & & & C.I. $95^{\circ}$ & $\operatorname{EXP}(B)$ \\
\hline & & B & E.T. & Wald & $\mathrm{gl}$ & Sig. & $\operatorname{Exp}(B)$ & Lower & Top \\
\hline Step $1^{\text {st }}$ & Capinno & 1,473 & ,408 & 13,030 & 1 & ,000 & 4,361 & 1,960 & 9,701 \\
\hline & Activity(1) & $-1,751$ &, 526 & 11,068 & 1 &, 001 & , 174 & ,062 & ,487 \\
\hline & Size & 1,105 &, 558 & 3,917 & 1 & ,048 & 3,019 & 1,011 & 9,015 \\
\hline & Constant & $-2,193$ & ,680 & 10,405 & 1 & ,001 &, 112 & & \\
\hline
\end{tabular}

With the data in the table we can construct the logistic regression equation (1):

$$
P(Y=1)=\frac{1}{1+\exp ^{\left(-\alpha-\beta_{1} X_{1}-\beta_{2} X_{2}-\beta_{3} X_{3}-\beta_{4} X_{4}\right)}}
$$

Where:

$$
\begin{array}{ll}
\mathrm{P}(\mathrm{Y}=1)= & \text { Internationalization probability of SMEs } \\
\alpha= & \text { Constant model } \\
B \mathrm{i}= & \text { Regression coefficient } \\
\mathrm{Xi}= & \text { Predictor variable value of the predictor }
\end{array}
$$

This equation predicted the likelihood of the outcome (internationalization) of a company given its activity, size and innovation capacity.

Table 6 shows SMEs' evaluations using different combinations of the most representative characteristics of the predictor variables included in the study. For example, if we were to evaluate equation in a small IT innovation company with media innovation capabilities, the prediction equation (2) would be:

$$
P(Y=1)=\frac{1}{1+\exp p^{(2.193+1.751(1)-1.105(1)-1.473(1))}}=0.20
$$

Thus, a chance of internationalization $\mathrm{P}(\mathrm{Y}=1)=0.20$ was obtained. With this predicted probability being less than 0.5 , and applying defined literature criteria (Aguayo, 2007), the company was necessarily classified as a company that was not internationalized.

By contrast, in the case of a small MM company with the same characteristics as the evaluated IT, the internationalization probability was $\mathrm{P}(\mathrm{Y}=1)=0.60$. As the probability was greater than 0.5 , it was classified as a company that was internationalized. The results of the statistical analysis (Table 5) confirmed that the greater the innovation capabilities of SMEs, the greater were their chances of becoming internationalized; these data proved the hypothesis.

Another important finding was that MM SMEs were more likely to become internationalized than IT SMEs, a phenomenon that may have been due to the specific activities carried out by these enterprises to meet their own market needs. In addition, the geographical location of the Mexican MMs - in close proximity to the market in the United States -gave these companies a strategic advantage as many US companies, in pursuit of cost reduction strategies, look to such companies for their supply or products. IT companies presented a different scenario, as the requirements with respect to information systems, implementation and maintenance, as well as costs and delivery times, made it difficult for such companies to rival foreign competitors. 
Table 5. Evaluation of SMEs as combinations of predictor variables.

\begin{tabular}{cccc}
\hline Size & Innovation & Activity \\
& Capabilities & IT & MM \\
\hline Micro & Low & 0.02 & 0.10 \\
Small & Low & 0.06 & 0.25 \\
Medium & Low & 0.15 & 0.50 \\
Micro & Average & 0.08 & 0.33 \\
Small & Average & 0.20 & 0.60 \\
Medium & Average & 0.44 & 0.82 \\
Micro & High & 0.27 & 0.68 \\
Small & High & 0.53 & 0.86 \\
Medium & High & 0.77 & 0.95 \\
\hline
\end{tabular}

Source: Based on data of the project: global production networks and local learning: spills of transnational technological and absorptive capacity in technology-based SMEs in northwest Mexico. COLEF-COLSON, CONACYT Project No. 133596.

\section{Conclusions}

Recognizing the difficulties faced by SMEs in directly participating in international markets, the solution proposed in this study is the insertion of such SMEs into global value chains established in the region. This option provides an opportunity to the companies to overcome some of the limitations which inhibit their ability to operate directly in foreign markets. In particular, the deficiencies are manifest in the following areas: production technologies; access to market information; and, the ability to design, produce, sell, distribute and provide after-sales service to meet the requirements of price, quality, time and flexibility of global market demands. However, even if the rhythms are different, for an SME to be accepted as a global network provider it must, nonetheless, enhance productivity and improve its innovation processes, thereby enabling it to maintain competitiveness.

The state of Sonora, Mexico, located on the border with the United States, has taken advantage of international trade agreements in order to attract direct foreign investment and, arising from its geographical location, has been favored by large transnational installation companies primarily in the automotive, aerospace and electronics sectors; these companies shape global value chains, and, in selecting foreign suppliers, evince a preference for companies with a minimum proven industry participation.

The innovative capacities of SMEs in Sonora are emerging and focus mostly on process development and (to a lesser extent) product enhancement; little emphasis is placed on organisational efficiency and marketing strategy. The companies, however, have not been able to position themselves in the global market or to become fully integrated as suppliers to large companies. Furthermore, few have been able to implement and develop their capacity for innovation, the necessary prerequisites for internationalization.

The study results showed that metalworking SMEs are more likely to be accepted as multinational providers than information technology SMEs. This is largely attributable to the fact that the IT product is intangible. On the other hand, it is observed that, in order for an SME to be accepted as a provider to a multinational company, it must not only make internal efforts to boost aspects such as training staff level and the training of the leader himself, upgrading technology and enhancing production practices, but it must also secure the support of various actors that make up the Regional Innovation System such as higher education institutions, government, financial institutions, and business chambers. With such support, it is possible that the capacity of SMEs to absorb knowledge and learning and to show innovation may be strengthened, paving the way for their full integration into global value chains.

\section{References}

Alderete, A. M. (2006). Fundamentos del Análisis de Regresión Logística en la Investigación Psicológica. Evaluar, 6, $52-67$

Aguayo, M. (2007). Cómo hacer una Regresión Logística binaria "paso a paso" (I). Fundación Andaluza Beturia para la investigación en salud (FABIS). Recuperado de http://www.fabis.org/html/archivos/docuweb/Regres_log_1r.pdf con fecha 1 de agosto de 2013

Alonso, J. A. (2007). Fragmentación productiva, multilocaliación y proceso de internacionalización de la empresa. ICE Nuevos productos, nuevos mercados y nuevas formas de internacionalización. No. 838

Buckley, P., \& Casson, Mx. (1985). The economics theory of the multinational enterprise. McMillan: London

Buse, S., Tiwari, R., \& Herstatt, C. (2010). Global innovation: an answer to mitigate barriers to innovation in Small and Medium-sized enterprises? International Journal of Innovation \& Technology Management, 7(3), 215-227. http://dx.doi.org/ 10.1142/S021987701000197

Contreras, O., \& Olea, J. (2005). Estudio sobre el impacto de la ampliación de la Ford Motor Co. en Hermosillo, 
Sonora. Fundación México Estados Unidos para la Ciencia - El Colegio de Sonora.

Cordis. (2009). Community Research and Development Information Service, recuperado de: http://cordis.europa.eu/fp7/projects_en.html)

Etemad, H., \& Wright, R. W. (1999). Internationalization of SMEs: Management response to a changing environment. Journal of International Marketing, 7(4), 4-10.

Feenstra, R. C. (1998). Integration of Trade and Disintegration of Production in the Global Economy. Journal of Economic Perspectives, 12(4), 31-50.

Fernández-Ortiz, R., San Emeterio, M., \& Menorca, L. (2012). A quantitative measure of the gradualist approach to internationalization. Global Journal of Business Research (GJBR), 6(3), 23-35.

Guiliani, E., Pietrobelli, C., \& Rabelloti, R. (2005). Upgrading Global Value Chains: Lessons from Latin American Clusters. World Development, 33(1), 549-573. http://dx.doi.org/10.1016/j.worlddev.2005.01.002

Hernández S. R., Fernández, C. C., \& Baptista, P. (2010). Metodología de la investigación (5a ed.), México: Mc Graw-Hill.

Jamali, M., Jawad, H., Shaikh, N., Shaikh, F., \& Afridi, T. (2011). Internationalization of SMES and organizational factors in a developing country: (a case study of ICT industry in Pakistan). Australian Journal of Business \& Management Research, 1(7), 129-138.

Johanson, J., \& Vahlne, J. (1977). The internationalization process of the firm. A model of knowledge development and increasing foreign market commitments. Journal of International Business Studies, 8(1), 25-34

Johanson, J., \& Vahlne, J. (2009). The Uppsala internationalization process model revisited: From liability of foreignness to liability of outsidership. Journal of International Business Studies.

Korsakiene, R. (2014). Internationalization of Lithuanian SMEs: Investigation of Barriers and Motives. Economics \& Business, 2654-60. http://dx.doi.org/ 10.7250/eb.2014.020

Korsakienè, R., \& Tvaronavičienė, M. (2012). The internationalization of SMEs: an integrative approach. Journal of Business Economics \& Management, 13(2), 294-307. http://dx.doi.org/ 10.3846/16111699.2011.620138

Kosakoffi, B., \& López, A. (2008). América Latina y las Cadenas Globales de Valor: debilidades y potencialidades. Globalización, Competitividad y Gobernabilidad, 2(1), 18-32. http://dx.doi.org/ 10.3232/GCG.2008

Küster, I., \& Vila, N. (2011). The market orientation-innovation-success relationship: The role of internationalization strategy. Innovation: Management, Policy \& Practice, 13(1), 36-54. http://dx.doi.org/ 10.5172/impp.2011.13.1.36

INEGI. Censos Económicos (2009). Micro, Pequeña, Mediana y Gran Empresa. Estratificación de los Establecimientos Leonidou, L. C. (2004). An Analysis of the Barriers Hindering Small Business Export Development. Journal of Small Business Management, 42(3), 279-302.

Leonidou, L. C., \& Katsikeas, C. S. (1997). Export information sources: the role of organizational and internationalization influences. Journal of Strategic Marketing, 5(2), 65-87. http://dx.doi.org/ $10.1080 / 096525497346802$

London, K. (2010). Multi-Market Industrial Organizational Economic Models for the Internationalization Process by Small and Medium Enterprise Construction Design Service Firms. Architectural Engineering \& Design Management, 6(2), 132-152. http://dx.doi.org/ 10.3763/aedm.2009.0111.

López Duarte, C., \& Ruiz Vega, A. (1996). Alternativas de penetración de los mercados exteriores: aplicación al caso de la República de Cuba. Revista Alta Dirección, 190, 91-108

Morrison, A., Pietrobelli, C., \& Rabelloti, R. (2008). Global Value Chains and Technological Capabilities. Oxford Development Studies, 36(1), 39-58. http://dx.doi.org/10.1080/13600810701848144

OECD (2005). Guía para la recogida e interpretación de datos sobre innovación, "Manual Oslo”, Eurostat

Organization for Economic Cooperation and Development (OECD) (2004). Promoting SMEs for Development: The Enabling Environment and Trade and Investment Capacity Building. Part II. Recuperado de http://www.oecd.org/dataoecd/6/7/31919278.pdf

Oviatt, B. M., \& McDougall, P. P. (2005). Defining International Entrepreneurship and Modeling the Speed of Internationalization. Entrepreneurship: Theory \& Practice, 29(5), 537-553

Oyson, M. (2011). Internationalisation of value chain activities of small firms: An international value chain approach. Small Enterprise Research, 18(2), 100-118.

Pietrobelli, C., \& Rabelloti, R. (2009). Upgrading in Clusters and Global Value Chains. Washington: Inter-American Development Bank.

Porter, M. E., \& Stern, S. (2001). Innovation: location matters. MIT Sloan Management Review, 42(4), 28-36.

Ruzzier, M., Antoncic, B., Hisrich, R. D., \& Konecnick, M. (2007). Human Capital and SME Internationalization: A Structural Equation Modeling Study. Canadian Journal of Administrative Sciences, 24(1), 15-29. http://dx.doi.org/ 10.1002/CJAS.3

Schuschny, A., \& Soto, H. (2009). Guía metodológica diseño de indicadores compuestos de desarrollo sostenible. 
Comisión Económica Para América Latina y El Caribe. CEPAL. Recuperado de http://www.eclac.cl/publicaciones/xml/7/36127/W255-2.pdf

Shen, H., Wang, L., Xu, Q., Li, Y., \& Liu, X. (2009). Toward a framework of innovation management in logistics firms: A systems perspective. Systems Research \& Behavioral Science, 26(2), 297-309. http://dx.doi.org/ 10.1002/sres.963

SIEM Sistema de Información Empresarial Mexicano. Recuperado de http:/www.siem.gob.mx

Valenti, G. (2008). Situando la agenda de los Sistemas Nacionales de Innovación. Incluido en el libro Ciencia, Tecnología e Innovación. Hacia una agenda de política pública. Flacso, 13-25

Zawislak, P., Borges, M., Wegner, D., Santos, A., \& Castro-Lucas, C. (2008). Towards the Innovation Function. Journal of Technology Management \& Innovation, 3(4), 17-30.

Korsakiene, R. (2014). Internationalization of Lithuanian SMEs: Investigation of Barriers and Motives. Economics \& Business, 2654-60. http://dx.doi.org/ 10.7250/eb.2014.020

\section{(cc) $\mathrm{BY}$}

This work is licensed under a Creative Commons Attribution 3.0 License. 